\title{
Avian Myeloblastosis Virus
}

National Cancer Institute

\section{Source}

National Cancer Institute. Avian Myeloblastosis Virus. NCI Thesaurus. Code C14247.

A retro-transcribing virus, of the genus Alpharetrovirus and the family Retroviridae, that causes anemia and malignant disease in wild and domestic fowl. 